\section{Introduction: \\ History as \\ Diagnosis}

\section{Martin Wiklund [*]}

\section{Pedro Spinola Pereira Caldas [**]}

$\left.{ }^{[*}\right]$ Stockholm University, Department of Culture and Aesthetics, Stockholm, Sweden. martin.wiklund@ idehist.su.se

ORCID: 0000-0001-9267-9353

[**] Universidade Federal do Estado do Rio de Janeiro (UniRio), Departamento de História, Rio de Janeiro, RJ, Brasil.pedro.caldas@gmail.com

ORCID: 0000-0001-9875-4545

\begin{abstract}
The very idea of a theme issue about History as Diagnosis emerged from a need to show how Historical Theory could be understood as an independent approach towards ready-made theories and abstract models, especially in historical moments immediately perceived as critical. The idea of history as diagnosis offers possibilities of interpreting symptoms and identifying pathologies in both society and in research in an empirically sensitive and theoretically innovative way
\end{abstract}

Keywords: Diagnosis; Crisis; Historical Theory.

\section{Introdução: História como diagnóstico}

Resumo: A ideia deste dossiê temático sobre História como Diagnóstico surgiu da necessidade de mostrar como a Teoria da História pode ser compreendida como uma abordagem independente perante teorias pré-fabricadas e modelos abstratos, especialmente em modelos percebidos imediatamente como críticos. A ideia de diagnóstico oferece, então, possibilidades de interpretar sintomas e identificar patologias tanto na sociedade como na pesquisa de uma maneira empiricamente sensível e teoricamente inovadora.

Palavras-chave: Diagnóstico; Crise; Teoria da História. 
Hey, don't be afraid, don't try to run away, because pain can be your friend, as it explains, the answers to your questions... ${ }^{1}$

Matt Johnson

1 he theme of this issue is guided by an interest in finding more perceptive forms of critical analysis of contemporary society and new forms of approaching theories in historical research. Medical or therapeutic concepts such as crisis, pathology, diagnosis and trauma abound in critical theories and historiography about modern society. While such concepts can be problematical (Roitman, 2014), they also contain a potential of a more productive approach to theoretical perspectives. Quite a lot of historical research applies standardized theoretical perspectives to particular historical cases, where the 'pathology' or content of a crisis is largely determined by the theoretical perspective chosen. What if the point of departure was rather: how could we theorize about this phenomenon, this tendency, this problem?

In order to further a more critical and innovative form of diagnosing crises and problems in society, we have combined the theme of history as diagnosis with an interest in the need for independent theorizing. Before we present the papers included in the issue, we will briefly outline a history of 'history as diagnosis' and say a few words about the background to the theme.

The ancient Greek concept of diagnosis is etymologically connected to both knowing (gnosis) and separation (dia-) and related to the Greek verb diagnoskein, which meant to examine carefully and distinguish abnormal phenomena in a medical context. The concept thus combined a dimension of knowledge and a dimension of discerning perception with reference to a normal or healthy condition. It is worth noting the closeness of meaning to two other Greek concepts that have been fundamental for the concept of critique: Krisis (judgment, separation, decision) and Diakrisis (discernment, distinction) (Kudlien, 1971-2007).

Although the medical metaphors or illnesses, cures and doctors were used already in ancient historiography and political thought by Thucydides, Plato and Polybios among others (Demandt, 1978, pp. 25-27), it was above all from the late eighteenth and in the nineteenth century that the application of medical concepts and metaphors to society became influential in historiography. With the development of the modern form of historical thinking and the idea of 'History' as a coherent process, 'crisis' turned into a central conceptual tool for making diagnoses of the present (Koselleck, 1972). Koselleck has pointed

' From the song "Phantom Walls", written by Matt Johnson (The The). 
to the problematical dualist and moralist character of the concept of crisis used in political discourse leading up to the French revolution. The kind of philosophy of history developed during the late eighteenth century tended to conceal the controversial nature of the 'crisis' and naturalize it in terms of 'the historical development' (Koselleck, 1959).

One important thread in the history of diagnosis is the tradition of social philosophy, with Rousseau's critique of modern civilization as an early case. As Honneth points out, a typical aspect of such diagnoses is the identification of negative trends of development, such as alienation and inequality. 'Crisis' has in this context often been used to draw attention to an alarming situation and an imminent turning point as well as to prognosticate the coming end of the current era. Marx' critical analysis of modern capitalism, which has been a major source of inspiration for diagnostical thinking in the twentieth century, is a key example (Honneth, 2000; Habermas, 1973).

During the nineteenth century, the use of medical and biological concepts in social thought became influential via the preference for organicist metaphors in romanticism, the triumphs of medicine, the influence of darwinism and the rise of vitalist and naturalist worldviews. Social, cultural and political problems were treated in terms of illnesses and 'degeneration.' With reference to an expected evolution or cultural flourishing, contemporary social and cultural phenomena that deviated from such expectations could appear as pathological. It was especially in the late nineteenth century and early twentieth century that 'diagnosis' became explicitly used as a form of cultural critique, significantly so in Nietzsche's diagnoses of European culture suffering from an excess of historical knowledge and, more fundamentally, of nihilism. Freud's psychoanalysis also became a vital source of inspiration for diagnostical perspectives of psychological and political disorders, most obviously perhaps in the Frankfurt School, one of the main currents of thought engaged in making diagnoses of the present (Honneth, 2007; 2001).

Another significant form of historical diagnosis of the present is represented by Michel Foucault. Foucault is especially interesting in this context also because a rather stereotyped form of 'Foucault' has been used a lot in historical research, despite that Foucault himself understood critical analysis in a very different way. He described his own form of history as 'a diagnosis of the present of a culture,' as an excavation of subterranean layers of contemporary thought. The aim of this kind of investigation was not to construct a general, stable theory of contemporary society, but rather to promote self-reflection, self-problematization and self-transformation - to examine the present in order to make it possible to transcend it and to think and act in a different way. ${ }^{2}$ One aspect of Foucault's work that is

2 Precisely the character of Foucault's philosophy as diagnosis of the present is in focus in the insightful analysis by Raffnsøe, Gudmand-Høyer and Thaning (2016) 
particularly relevant for this theme issue is the philosophically productive role of empirical historical research in the elaboration of his diagnoses, as opposed to applying ready-made models of interpretation.

As can be seen from the historical outline above, diagnoses of the present have often been formulated by sociologists, who combine social philosophy and empirical research with an historical perspective of social development. How could historians develop their ability to create independent and innovative diagnoses of the problems and pathologies of society, a political regime or a cultural tendency? How can historians cope perceptively and critically with 'crises' and with so called 'limit-events' such as the Shoah. Hiroshima, Chernobyl, genocides and civil wars?

To throw light on how historians can make historical diagnoses, we have brought together papers by scholars from different parts of the world that analyse history as diagnosis in different historiographical fields, with an emphasis on philosophers and historians in France, Spain and Germany in the twentieth century. As the reader will find, the papers are related to different aspects of the historical outline above, from Nietzsche and Freud to Foucault and Critical Theory.

Egon Bauwelinck's paper on Charles Péguy's use of diagnosis as a metaphor shows how historical knowledge and political concerns merge in a way that demands sophisticated answers. Péguy was critical of the tendency of the Socialist party to stick to earlier diagnoses and pointed to the importance of examining problems and illnesses properly and of being able to accept one's own illness. An intriguing aspect of the paper concerns the importance of mutual truthfulness between the doctor/historian and the patient/audience for the diagnosis to function as a remedy. Bauwelinck's analysis of Péguy's role as an intellectual invites us to think that at the core of historical sensibility is an ethical component, in which sincerity and frankness plays a major role.

Juan Luis Fernández' paper analyses a plurality of examples of historical diagnoses in Spanish history writing in the twentieth century and reveals how specific diagnoses were linked to preferred political "remedies" and solutions. The examples show how historical diagnoses were developed in different ways and responded to other narratives. Fernández also analyses the theoretical elements of these diagnoses and makes a contribution to the understanding of the general character of historical diagnoses, consisting of a general framework, a plot pattern, a diagnosis and a suggested therapy.

The relevance of our theme to a field of research such as history of science may not be obvious at first sight, but Tiago Almeida's analysis of Gaston Bachelard's philosophical history of science sheds light on how history of science and reason can provide a critical diagnosis of the present, articulating the obstacles to further development of science and reason and making possible a transvaluation of epistemological norms. Bachelard's idea of 
a turbulent reason corresponds to diagnosis as an inevitably turbulent process, due to the interdependence between the interpretation and judgment of the past and the diagnosis of the norms of the present.

In a sense, Pedro Caldas' paper on the concept of limit event also deals with how a specific scientific discipline can perceive and diagnose its own symptoms, but in this case focuses on historiography. The limit event turns out to be an event that challenges the historian and his or her patterns of interpretation, but in order to be able to perceive that, the historian needs to let him- or herself be affected by the event. Could Angstbereitschaft, the capacity to feel Angst, perhaps be a necessary epistemic virtue for being able to identify limit events that challenge our sense making patterns of historical orientation? Thus, although the paper deals mainly with contemporary historiography, it ties in with Péguy's emphasis on the epistemological and ethical need for perceptive frankness and the readiness to be diagnosed as ill.

In a few words: we hope that the reader can see how history as diagnosis contains several possibilities and how it often involves a quite complex, self-referential task, and that it may concern problematical symptoms both in society and in research. This suggests that we could hardly exclude ourselves from such a task: what about our own diagnosis? In a certain sense, our interest in history as diagnosis can in itself be interpreted as a symptom. We felt that something was itching, a kind of intellectual irritation with how theories are often used and applied, and felt the need to look for alternative approaches. That is a problem not only for research, but also for public debate, where 'crises' are proclaimed and explanations of problems are sometimes launched in an instrumentalist way to further particular political aims. Diagnoses tend to become reified and turn into ready-made perspectives in a way that short-circuits the responsibility and capacity to make independent interpretations and to develop new theoretical perspectives.

The interest in new diagnoses is not merely a symptom of our concern for the development of research, but also a reaction to the problematic character of present society and our dissatisfaction with the usual diagnoses. This bi-focal perception of, on the one hand, the critical state of society and, on the other, the tendency to launch ready-made identifications and judgments of the problems in the present, pointed in the direction of trying to stimulate the development of more innovative, perceptive and dynamic forms of critique and diagnosis. The theme of this issue can thus be seen as motivated both by the pathologies that historical theory suffers from and the pathologies of our present societies. 


\section{References}

DEMANDT, Alexander. Metaphern für Geschichte: Sprachbilder und Gleichnisse im historisch-politischen Denken. München: C. H. Beck, 1978.

HABERMAS, Jürgen. Legitimationsprobleme im Spätkapitalismus. Frankfurt am Main: Suhrkamp, 1973.

HONNETH, Axel. Pathologien des Sozialen. Tradition und Aktualität der Sozialphilosophie. In: HONNETH, Axel. Das Andere der Gerechtigkeit. Frankfurt am Main: Suhrkamp, 2000. pp. 11-69.

HONNETH, Axel. Leiden an Unbestimmtheit. Stuttgart: Reclam, 2001.

HONNETH, Axel. Pathologien der Vernunft. Frankfurt am Main: Suhrkamp, 2007.

KOSELLECK, Reinhart. Kritik und Krise: Eine Studie zur Pathogenese der bürgerlichen Welt. Freiburg im Breisgau: Karl Alber, 1959.
KOSELLECK, Reinhart. Krise. In: BRUNNER, Otto; KONZE, Werner; KOSELLECK, Reinhart (eds.). Geschichtliche Grundbegriffe: Historisches Lexicon zur politisch-sozialen Sprache in Deutschland. Bd. 3, Stuttgart: Klett-Cotta, 1972.

KUDLIEN, Fridolf. Diagnose. In: RITTER Joachim; GRÜNDER, Karlfried; GABRIEL, Gottfried (eds.). Historisches Wörterbuch der Philosophie, Bd. 2. Basel: Schwabe, 1971-2007.

RAFFNSØE, Sverre; GUDMAN-HØYER, Marius; THANING, Morten. Michel Foucault: A Research Companion. Basingstoke, UK: Palgrave Macmillan, 2016.

ROITMAN, Janet. Anti-Crisis. Durham: Duke University Press, 2014. 